UDC 66.01: 66.065.32

K. Luskan,

A. Gyrenko, $\mathrm{PhD}$, Assoc. Prof.,

O. Musov, PhD, Assoc. Prof.,

M. Savchenko, $\mathrm{PhD}$, Assoc. Prof.,

O. Klimenko, $\mathrm{PhD}$

Ukrainian State University of Chemical Technology, 8 Gagarin Ave., Dnipropetrovsk, Ukraine, 49005; e-mail: katerynalu16@ gmail.com

\title{
INFLUENCE OF THE PARAMETERS OF THERMAL DECOMPOSITION OF AMMONIUM TETRAVANADATE ON THE PROCESSES OF PHASE FORMATION OF HIGHLY DISPERSED VANADIUM OXIDES
}

\begin{abstract}
К.В. Лускань, А.О. Гиренко, О.П. Мисов, М.О. Савченко, О.П. Клименко. Вплив параметрів термічного розкладання амоній тетраванадату на процеси фазоутворення високодисперсних оксидів ванадію. Досліджені особливості термічного розкладання високодисперсної солі вананадію (IV) - амоній тетраванадату, що є прекурсором для одержання нанокристалічних оксидів ванадію різного ступеню окислення $\left(\mathrm{V}_{2} \mathrm{O}_{5}, \mathrm{VO}_{2}\right)$. Метою експериментальних досліджень $\epsilon$ встановити вплив параметрів термічного розкладання амоній тетраванадату на процеси фазоутворення високодисперсних продуктів оксидів ванадію $\left(\mathrm{V}_{2} \mathrm{O}_{5}\right.$, $\left.\mathrm{VO}_{2}\right)$. Оптичною мікроскопією та порошковою рентгенівською дифракцією досліджено залежність фазо утворення та розмір частинок діоксиду ванадію від температури термодеструкції. Термообробка амоній тетраванадату у окисній атмосфері при температурі $400 \ldots 500{ }^{\circ} \mathrm{C}$ призводить до утворення пентаоксиду ванадію $\left(\mathrm{V}_{2} \mathrm{O}_{5}\right)$, інертна атмосфера сприяє утворенню діоксиду ванадію (VO $)$ при $850 \ldots 900^{\circ} \mathrm{C}$. Визначен оптимальний температурний режими оброки амоній тетраванадату для отримання нанокристалічного діоксиду ванадію з присутнім йому фазовим переходом (ФП).

Ключові слова: амоній тетраванадат, оксиди ванадію, термічне розкладання, фазоутворення

K. Luskan, A. Gyrenko, O. Musov, M. Savchenko, O. Klimenko. Influence of the parameters of thermal decomposition of ammonium tetravanadate on the processes of phase formation of highly dispersed vanadium oxides. The peculiarities of the thermal decomposition of the highly dispersed vanadium (IV) ammonium tetrabutanate salt, which is a precursor for the production of nanocrystalline vanadium oxides of different degrees of oxidation $\left(\mathrm{V}_{2} \mathrm{O}_{5}, \mathrm{VO}_{2}\right)$, are studied. The purpose of experimental studies is to determine the influence of the parameters of thermal decomposition of ammonium tetravanadate on the processes of phase formation of nanocrystalline products of vanadium oxides $\left(\mathrm{V}_{2} \mathrm{O}_{5}, \mathrm{VO}_{2}\right)$. Optical microscopy and powder X-ray diffraction investigates the dependence of phase-formation and the size of vanadium dioxide particles on the temperature of thermal degradation. Heat treatment of ammonium tetravanadate in an oxidizing atmosphere at a temperature of $400 \ldots 500{ }^{\circ} \mathrm{C}$ leads to the formation of vanadium pentoxide $\left(\mathrm{V}_{2} \mathrm{O}_{5}\right)$, the inert atmosphere contributes to the formation of vanadium dioxide $\left(\mathrm{VO}_{2}\right)$ at $850 \ldots 900{ }^{\circ} \mathrm{C}$. The optimum temperature regimes of tetravanodate ammonium trim have been determined for the production of nanocrystalline vanadium dioxide with the phase transition present therein.

Keywords: ammonium tetravanadate, vanadium dioxides, thermal destruction, phase formation
\end{abstract}

Introduction. Vanadium dioxide $\left(\mathrm{VO}_{2}\right)$ as a material for optics and electronics has attracted the attention of researchers for many decades. The reason for this is the reversible phase transition of the semiconductor-metal (PTSM), which is accompanied by an extremely strong change in optical and electrical properties of the material. Unique characteristics of this connection allow it to be used in temperature sensors, optical switches, memory elements, energy-saving coatings for glass, optical data carriers and thermochromic indicators [1-3].

Despite the wide possibilities for the practical use of volumetric samples of vanadium oxides, many of them have not yet been implemented. The reason is the mechanical stress that occurs when PTSM, which leads to the destruction of crystals in the process of cyclic switching. In this connection, many modern experiments are aimed at developing methods for obtaining film materials [4-6] however, the use of films is limited because of the impossibility of their application in the field of significant electric currents.

DOI: 10.15276/opu.1.54.2018.11

(C) 2018 The Authors. This is an open access article under the CC BY license (http://creativecommons.org/licenses/by/4.0/). 
Previous studies have shown [7] that the mechanical voltage in $\mathrm{VO}_{2}$ is diminished with a decrease in the geometric sizes of crystals to $100 \mathrm{~nm}$, which allows obtaining materials with stable characteristics in the process of thermocycling. For example, reducing the size of particles of vanadium oxide powder from micro to nanometers can not only improve the mechanical characteristics of ceramic materials on the basis of $\mathrm{VO}_{2}$, but also substantially change the properties of the substance. In this case, the changes relate to the main characteristics of the solid: 1) the parameters of the grid; 2) electronic structure; 3 ) melting point and phase transformation; 4) diffusion rate and chemical reactions.

From the technological and economic point of view, one of the most promising ways of synthesizing of nanocrystalline vanadium oxides is the thermal decomposition of the precursor-highly dispersed salt of ammonium tetravanadate. The regulation of technological parameters at the stage of synthesis as well as at the stage of thermal decomposition of tetravanadate ammonium can control the physical and chemical properties of vanadium oxides [8].

Despite the unique properties of tetravanadate ammonium, the conditions for its thermal decomposition are not fully understood, which prevents the optimization of the technological process. Thus, the development of technology for the production of nanodispersed powders of vanadium oxides from tetravanadate ammonium is an urgent task.

The aim of the study. On the basis of experimental studies, to determine the influence of thermal decomposition parameters of tetravanadate ammonium on the processes of phase formation of anticrystalline products of vanadium oxides $\left(\mathrm{V}_{2} \mathrm{O}_{5}, \mathrm{VO}_{2}\right)$. To achieve this goal, the following issues were solved:

- to determine the influence of the decomposition atmosphere on the phase composition of the product of vanadium oxides;

- to determine the optimum temperature of the thermal decomposition of tetravanadate ammonium to obtain a nanocrystalline $\mathrm{VO}_{2}$ with the phase transition of the semiconductor-metal it is present.

Materials and methods. Salt - ammonium tetravanadate $\left(\mathrm{NH}_{4}\right)_{2} \mathrm{~V}_{4} \mathrm{O}_{9}$, which is a precursor for the synthesis of vanadium oxides, was prepared by the interaction of $\mathrm{V}_{2} \mathrm{O}_{55}$ with an aqueous solution of oxalic acid during heating, followed by the precipitation of ammonium hydroxide to $\mathrm{pH} 9.1 \ldots 9.3$ by centrifugation, washing and drying the product in an atmosphere of argon [9]. Drying in an inert atmosphere at $150 \ldots 180^{\circ} \mathrm{C}$ is required for salt storage, since the presence of water promotes the rapid oxidation of vanadium to a five valent state.

At the final stage of the technology, the dried salt of tetravanadate ammonium was thermally decomposed in air and in a neutral atmosphere of argon.

The decomposition of the precursor in the air flow was carried out in the electric furnace of the brand SNOL 8.2/1100 U4A to a temperature of $400 \ldots 500{ }^{\circ} \mathrm{C}$, and in the atmosphere of argon in a specially furnished furnace (Fig. 1) in the temperature interval of $380 \ldots 900{ }^{\circ} \mathrm{C}$.

The speed of heating in both cases was $5^{\circ} \mathrm{C} / \mathrm{min}$. with an endurance in time of $10 \ldots 15 \mathrm{~min}$. To prevent the oxidation of vanadium dioxide, the cooling of the resulting powders was carried out in an inert atmosphere.

The total amount of vanadium $\left(\mathrm{V}^{+4}, \mathrm{~V}^{+5}\right)$ in the synthesized powders was determined by titration of the Mora salt by the method [10].

Investigation of the phase composition of vanadium oxide products formed after thermal treatment of ammonium tetrabutanate salt in an inert atmosphere at different temperatures $\left(380 \ldots 900{ }^{\circ} \mathrm{C}\right)$ was carried out by X-ray diffraction analysis.

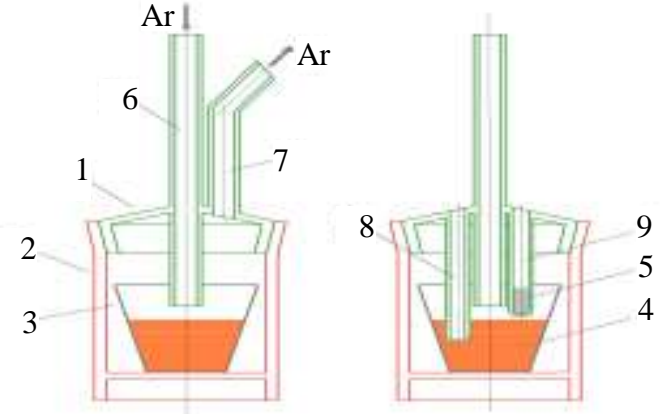

Fig. 1. Designed furnace for decomposition of tetravanadate ammonium: 1 - quartz reactor, 2 oven, 3 - porcelain tigel, 4 -weight $\left(\mathrm{NH}_{4}\right)_{2} \mathrm{~V}_{4} \mathrm{O}_{9}$, 5 - weight $\mathrm{SiO}_{2}, 6$ - capacity for supply of argon, 7 - capacity for gas exhaust in decomposition process, 8, 9 -thermocouples 
X-ray diffraction analysis was performed on a DRON-2.0 diffractometer using $\mathrm{CuK}$ a radiation $(1=0.15418 \mathrm{~nm}$.) In the mode: voltage $35 \mathrm{kV}$, current $10 \mathrm{~mA}$.

The morphology of the powders was conducted by transducing electron microscopy using a JEM-100 cCXII microscope.

The study of the temperature of the phase transition in the final product $\mathrm{VO}_{2}$ was carried out by the method of DTA by the method [11].

The solubility of heat-treated powders was determined by obtaining a saturated solution of vanadium oxide followed by filtration of the mixture and determining the total amount of vanadium in the filtrate by the method [12].

Results. The salt $\left(\mathrm{NH}_{4}\right)_{2} \mathrm{~V}_{4} \mathrm{O}_{9}$ synthesized by us represents a crystalline powder of dark color with a density of $2.1 \mathrm{~g} / \mathrm{sm}^{3}$ and a bulk density of $1.1 \mathrm{~g} / \mathrm{sm}^{3}$, the water solubility is $5 \cdot 10^{-4} \mathrm{~mol} / 1[8,12]$.

The final stage of the technological process is the thermal treatment of tetravanodate ammonium to produce vanadium oxides with an available phase transition of a semiconductor-metal. Assume that thermal treatment at temperature intervals of $380 \ldots 900^{\circ} \mathrm{C}$ can affect the physical and chemical properties of the final products (phase composition, particle size, solubility, etc.). Therefore, an important step is to determine the optimal conditions for the thermal treatment of tetravanadate ammonium.

Determination of the influence of the oxidative atmosphere in the thermal decomposition of the precursor on the presence of vanadium ions $\left(\mathrm{V}^{+4}, \mathrm{~V}^{+5}\right)$ is shown in Fig. 2 .

Significant increase in the concentration of $\mathrm{V}^{+5}$ in the powder of ammonium tetravanadate at temperature treatment above $200^{\circ} \mathrm{C}$ is due to the oxidation of $\mathrm{V}^{+4}$ to $\mathrm{V}^{+5}$ by reaction 1

$$
\left(\mathrm{NH}_{4}\right)_{2} \mathrm{~V}_{4} \mathrm{O}_{9}+\mathrm{O}_{2} \rightarrow 2 \mathrm{NH}_{3} \uparrow+\mathrm{H}_{2} \mathrm{O}+2 \mathrm{~V}_{2} \mathrm{O}_{5} \text {. }
$$

According to reaction 1, to obtain $\mathrm{VO}_{2}$ decomposition of tetravanadate ammonium must be carried out in an argon stream (reaction 2):

$$
\left(\mathrm{NH}_{4}\right)_{2} \mathrm{~V}_{4} \mathrm{O}_{9} \rightarrow 4 \mathrm{VO}_{2}+2 \mathrm{NH}_{3}+\mathrm{H}_{2} \mathrm{O} \text {. }
$$

The diffraction patterns of the powders are obtained by the thermal decomposition of tetravanadate ammonium at temperatures of $380,450,650,900{ }^{\circ} \mathrm{C}$ shown in Fig. 3.

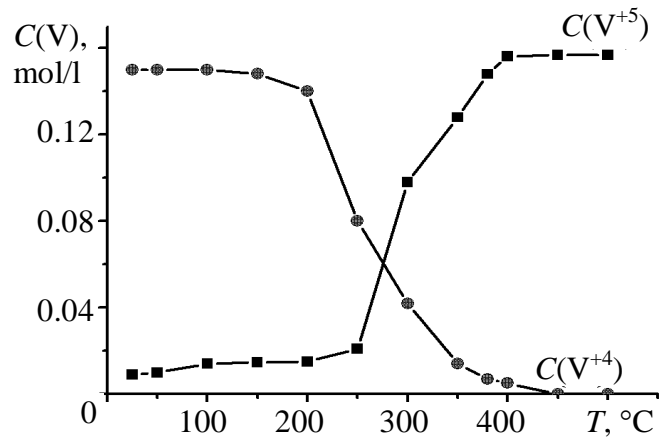

Fig. 2. Dependence of the content $V^{+4}, V^{+5}$ in the synthesis product on the decomposition temperature

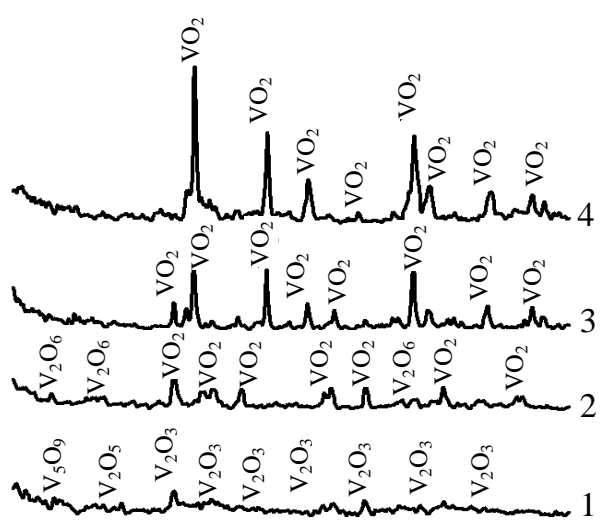

Fig. 3. The diffractograms of the heat treatment powder ammonium tetrabutanate for 10 minutes. with decomposition temperature: 1 -380; 2 - 450; 3 - 650; $4-900{ }^{\circ} \mathrm{C}$

As can be seen from Fig. 3. thermodegradation of powders at temperature intervals $380 \ldots 450{ }^{\circ} \mathrm{C}$ (curve 1,2) forms a mixture of various oxides of vanadium $\mathrm{V}_{2} \mathrm{O}_{3}, \mathrm{VO}_{2}, \mathrm{~V}_{5} \mathrm{O}_{9}, \mathrm{~V}_{2} \mathrm{O}_{5}$. With an increase in temperature to $650{ }^{\circ} \mathrm{C}$ (curve 3) there are low-intensity reflexes characteristic of the phase $\mathrm{VO}_{2}$. The temperature increase to $900{ }^{\circ} \mathrm{C}$ is characterized by the appearance of a crystalline phase $\mathrm{VO}_{2}$ with a monoclinic angle of $106.9^{\circ} \mathrm{C}$.

The study of the temperature of the phase transition of the obtained samples $\mathrm{VO}_{2}$ (with different thermal processing) is shown in the Fig. 4. 
Thermal degradation of $\left(\mathrm{NH}_{4}\right)_{2} \mathrm{~V}_{4} \mathrm{O}_{9}$ at $900{ }^{\circ} \mathrm{C}$ indicates the formation of vanadium dioxide with its corresponding electro-functional properties and an expressive endothermic peak at $68^{\circ} \mathrm{C}$ (Fig. 4).

The method of transmission electron microscopy determines the size of the vanadium oxide particles (Fig. 5, a) which does not exceed $80 \ldots 82 \mathrm{~nm}$.

Fig. 5, $b$ shows the dependence of the size of the particles of vanadium oxide products obtained from the heat treatment temperature $\left(380 \ldots 900{ }^{\circ} \mathrm{C}\right)$.

Fig. 6 shows the dependence of solubility in distilled water of $\mathrm{VO}_{2}$ powders on the temperature of thermal degradation

The solubility of vanadium dioxide powder obtained at a temperature of $650^{\circ} \mathrm{C}$ is $2.3 \cdot 10^{-4} \mathrm{~mol} / 1$ and at $900{ }^{\circ} \mathrm{C}$ the

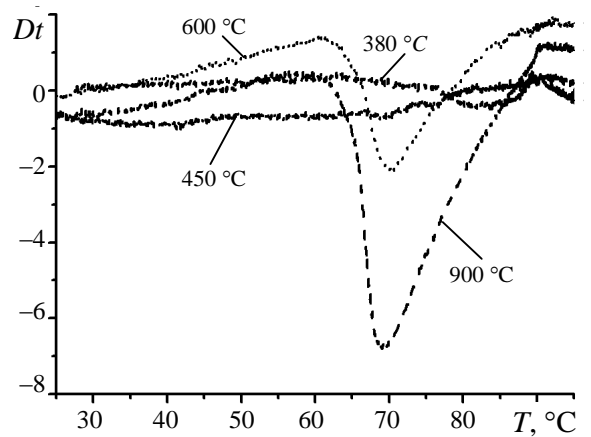

Fig. 4 DTA curves of vanadium dioxide obtained by thermal decomposition (NH4)2V4O9 for 10 minutes at temperatures $\left(380 \ldots 900{ }^{\circ} \mathrm{C}\right)$ powder is not soluble in distilled water.

Having analyzed the ability of Vanadium oxide powders to store it (Fig. 7) and the above data, it can be concluded that the temperature treatment at $900{ }^{\circ} \mathrm{C}$ is optimal for obtaining a chemically pure $(98 \%)$ nanocrystalline product with a characteristic phase transition of a semiconductor-metal.
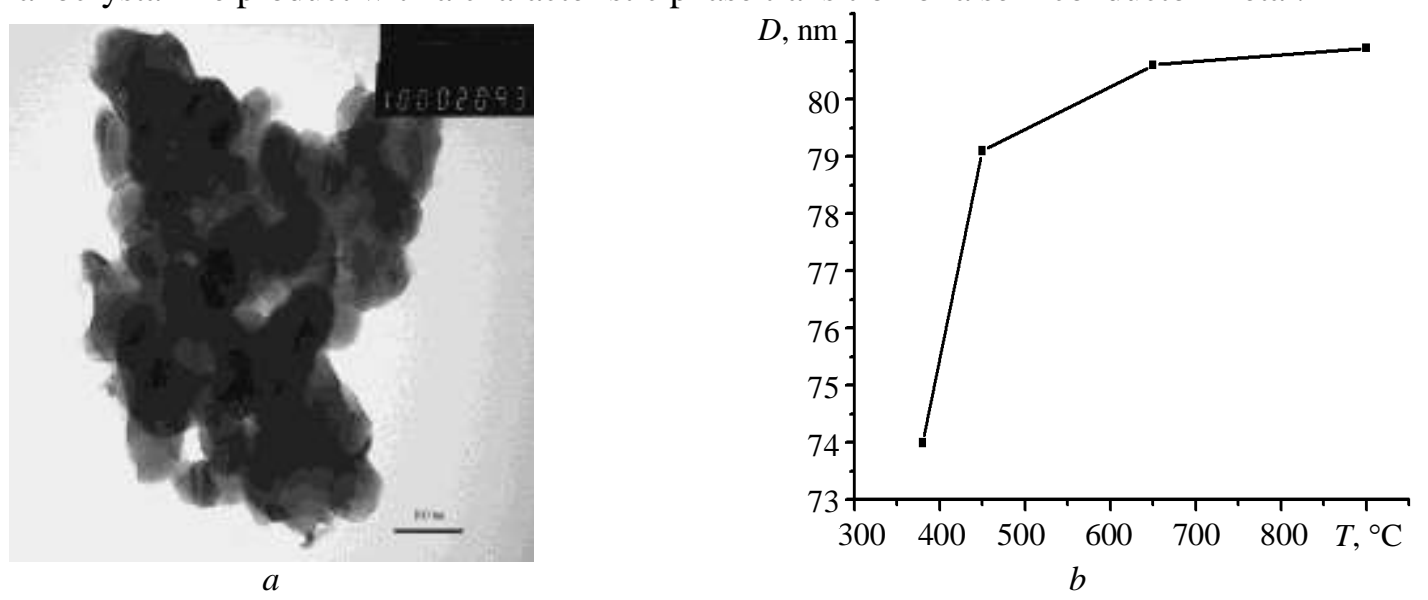

Fig. 5. Microphotography of $\mathrm{VO}_{2}$ obtained by thermal degradation $\left(\mathrm{NH}_{4}\right)_{2} \mathrm{~V}_{4} \mathrm{O}_{9}$ at $900{ }^{\circ} \mathrm{C}$ for 10 minutes with a particle size of $80 \ldots 82 \mathrm{~nm}(a)$; dependence of the size of vanadium oxide particles on the temperature of thermal decomposition $\left(\mathrm{NH}_{4}\right)_{2} \mathrm{~V}_{4} \mathrm{O}_{9}(b)$

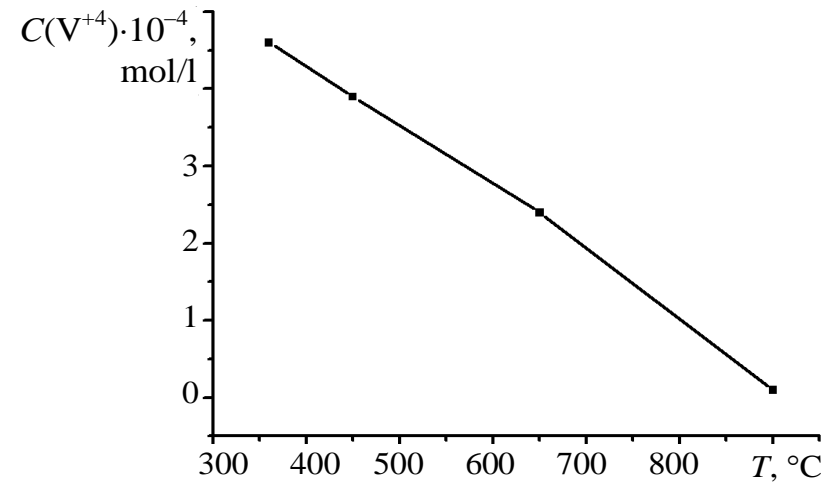

Fig.6. The dependence of solubility of $\mathrm{VO}_{2}$ on the temperature of thermal degradation $\left(380 \ldots 900^{\circ} \mathrm{C}\right)$ at 25 ${ }^{\circ} \mathrm{C}$

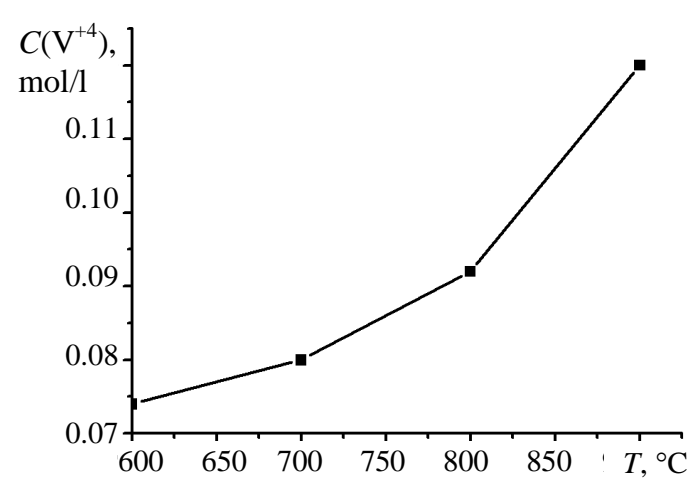

Fig. 7. The oxidative ability of vanadium dioxide powder obtained by thermal degradation

$\left(\mathrm{NH}_{4}\right)_{2} \mathrm{~V}_{4} \mathrm{O}_{9}$ at $600 \ldots 900{ }^{\circ} \mathrm{C}$ with an exposure time of 10 minutes when stored for two years 
Conclusion. Thus, on the basis of experimental studies, the influence of the parameters of thermal decomposition (temperature and decomposition atmosphere) of tetravanadate ammonium on the phase composition, particle size, solubility and oxidative ability during storage of highly dispersed vanadium oxides has been established.

Radiographs and results of transmitted electron microscopy confirmed and clarified the picture of phase transformations.

The high probability of oxidation of tetravanadate ammonium with its decomposition in the atmosphere of air with the formation of $\mathrm{V}_{2} \mathrm{O}_{5}$ at a temperature of $450 \ldots 500{ }^{\circ} \mathrm{C}$ was revealed.

It was found that thermal treatment $\left(\mathrm{NH}_{4}\right)_{2} \mathrm{~V}_{4} \mathrm{O}_{9}$ should be carried out in an inert atmosphere of argon.

It is shown that at temperature processing $380 \ldots 650{ }^{\circ} \mathrm{C}$ a mixture of various vanadium oxides with a water-solubility of $2.3 \ldots 4.6 \cdot 10^{-4} \mathrm{~mol} / \mathrm{l}$ is formed and which are capable of oxidizing during storage. The nanocrystalline $\mathrm{VO}_{2}$ with the particle size $80 \ldots 82 \mathrm{~nm}$ and its tributary PTSM (at a temperature of $68^{\circ} \mathrm{C}$ ) is formed as a result of thermal decomposition of $850 \ldots 900{ }^{\circ} \mathrm{C}$ for 10 minutes. Next, it is planned to conduct research on the effects of the conditions for the synthesis of ammonium tetravanadatuna, the size of the particles of vanadium dioxide.

\section{Література}

1. Wang H., Yi X., Chen S., Fu X. Fabrication of vanadium oxide micro-optical switches. Sensors and Actuators A: Physical. 2005. Vol. 122. P. 108-112.

2. External electric field manipulations on structural phase transition of vanadium dioxide nanoparticles and its application in field effect transistor / W.W. Li, et al. Physical. Chemistry. 2011. Vol. 115. P. 23558-23563.

3. Solution-based fabrication of vanadium dioxide on $\mathrm{F}: \mathrm{SnO}_{2}$ substrates withlargely enhanced thermochromism and low-emissivity for energy-savingapplications/ Z. Zhang., et al. Energy \& Environmental Science. 2011. Vol. 4. P.4290-4297.

4. Синтез пленок диоксида ванадия модифицированным золь-гель методом/ Д.А. Винниченко и др. Неорганические материалы. 2011. Т 47. С. 28-33.

5. Андреев В.Н., Климов В.А., Компан М.Е. Термическая литография тонких пленок диоксида ванадия. Письма в ЖТФ. 2016. Т 42. С. 42-48.

6. Синтез пленкообразующих материалов из оксидов ванадия и исследование возможностей получения на их основе оптических покрытий / В.В.Кириленко и др. Оптический журнал. 2010. T. 77. C. $75-87$.

7. Ivon A.I., Kolbunov V.R., Chernenko I.M. Conductivity stabilization by metal and oxide additives in ceramics on the basis of $\mathrm{VO}_{2}$ and glass $\mathrm{V}_{2} \mathrm{O}_{5}-\mathrm{P}_{2} \mathrm{O}_{5}$. J. Non-Cryst. Solids. 2005. Vol. 351. P. 3649-3654.

8. Luskan K.V., Gyrenko O. A, Musov O.P., Klimenko O.P. Influence of the conditions for the preparation and thermal destruction of ammonium tetravanadate on the composition of oxide-vanadic electrofunctional materials. Odes'kyi Politechnichnyi Universytet. Pratsi. 2017. Vol. 2. P. 87-92.

9. Спосіб отримання нанодисперсного порошку тетраванадату амонію: пат. 104512 Україна: № u201506327; заявл. 26.06.2015; надр. 10.02.2016, Бюл №3.

10. Спосіб визначення в окислах вмісту чотири- і п'ятивалентного стану ванадію при іх спільній присутності: пат. 49664 Україна. № u200910634; заявл. 21.10.2009; надр. 11.05.2010, Бюл № 9.

11. Карніна, О.Ю., Клименко О.П., Мисов О.П. Оцінка невизначеності вимірювання критичної температури при дослідженні фазового переходу напівпровідник-метал у діоксиді ванадію. Системи обробки інформащії. 2015. Т 6. С. 84-87.

12. Luskan K.V., Gyrenko A., Bubel T., Mysov O. Synthesis and physicochemical properties of ammonium tetravanadate for obtaining $\mathrm{VO}_{2}$. Chemical Techology. 2017. Vol. 11. P. 247-252.

\section{References}

1. Wang H, Yi X., Chen S., Fu X. (2005). Fabrication of vanadium oxide micro-optical switches. Sensors and Actuators A: Physical, 122, 108-112. 
2. Li W.W., Zhu J.J., \& Liang J.R. et al. (2011). External electric field manipulations on structural phase transition of vanadium dioxide nanoparticles and its application in field effect transistor. Physical. Chemistry, 115, 23558-23563.

3. Zhang Z., Gao Y., \& Luo H., et al. (2011). Solution-based fabrication of vanadium dioxide on F: $\mathrm{SnO}_{2}$ substrates withlargely enhanced thermochromism and low-emissivity for energy-savingapplications. Energy \& Environmental Science, 4, 4290-4297.

4. Vinnichenko D.A., Vasiliev V.A., Seregin D.S., \& Berezina, O.Ya. (2011). Synthesis of vanadium dioxide films modified by sol-gel method. Inorganic materials, 47, 28-33.

5. Andreev V.N., Klimov V.A., \& Company M.E. (2016). Thermal lithography of thin films of vanadium dioxide. Letters to ZhTF, 42, 42-48.

6. Kirilenko V.V., Zhigarnovsky B.M., \& Beyrakhov A.G. et al. (2010). Synthesis of film-forming materials from vanadium oxides and study of the possibilities of obtaining optical coatings on their basis. Optical Journal, 77, 75-87.

7. Ivon A.I., Kolbunov V.R., \& Chernenko I.M. (2005). Conductivity stabilization by metal and oxide additives in ceramics on the basis of $\mathrm{VO}_{2}$ and glass $\mathrm{V}_{2} \mathrm{O}_{5}-\mathrm{P}_{2} \mathrm{O}_{5}$. J. Non-Cryst. Solids, 351, 3649-3654.

8. Luskan K.V., Gyrenko O.A., Musov O.P., \& Klimenko O.P. (2017). Influence of the conditions for the preparation and thermal destruction of ammonium tetravanadate on the composition of oxide-vanadic electro-functional materials. Odes 'kyi Politechnichnyi Universytet. Pratsi, 2, 87-92.

9. Luskan K.V., Mysov O.P., \& Gyrenko A.O. (2016). Method nanodispersed powdered ammonium tetravanadatu. Ukraine Patent: UA 104512.

10. Chernenko I.M., Oliynyk O.Yu., \& Misov O.P. (2010). Method of determining the content of quaternary and pentavalent state of vanadium in the presence of a joint presence in the oxides. Ukraine Patent: UA 49664.

11. Carnina O.Yu., Klymenko O.P., \& Misov O.P. (2015). Estimation of Uncertainty in the Measurement of the Critical Temperature in the Study of the Phase Transition of a Semiconductor-Metal in Vanadium Dioxide. Systems of information processing, 6, 84-87.

12. Luskan K.V., Gyrenko A., Bubel T., \& Mysov, O. (2017). Synthesis and physicoc chemical properties of ammonium tetravanadate for obtaining $\mathrm{VO}_{2}$. Chemical Techology, 11, 247-252.

Лускань Катерина Вікторівна; Luskan Katerina, ORCID: http//orcid.org/0000-0002-8435-285X

Гиренко Альона Олександрівна; Girenko Alena, ORCID: http//orcid.org/0000-0002-1655-816X

Мисов Олег Петрович; Misov Oleg, ORCID: http//orcid.org/0000-0003-2114-1382

Савченко Марія Олегівна; Savchenko Maria, ORCID: https://orcid.org/0000-0003-0908-1604

Клименко Олександр Павлович; Klymenko Olexander, ORCID: http://orcid.org/0000-0003-4332-2790/

Received March 05, 2018

Accepted March 28, 2018 